\author{
JURNAL EINSTEIN \\ Jurnal Hasil Penelitian Bindang Fisika \\ Available online http://jurnal.unimed.ac.id/2012/index.php/inpafi \\ e-issn: $2407-747 x$, p-issn $2338-1981$
}

\title{
KARAKTERISASI UJI KEKUATAN TARIK (TENSILE STRENGHT) FILM PLASTIK BIODEGRADABLE DARI TANDAN KOSONG KELAPA SAWIT DENGAN PENGUAT ZINK OKSIDA DAN GLISEROL
}

\author{
Agustina Mandasari, Mutya Fika Safitri, Essy Risa Perangin-angin, Dian Sunarwati, \\ Wulan Dwi Safitri dan Hafni Indriati Nasution \\ Jurusan Fisika, Fakultas Matematika dan Ilmu Pengetahuan Alam, Universitas Negeri Medan, \\ Indonesia \\ agustinsitorus49@gmail.com \\ Diterima April 2017; Disetujui Mei 2017; Dipublikasikan Juni 2017
}

\begin{abstract}
ABSTRAK
Telah dilakukan karakterisasi uji kekuatan tarik (tensile strength) film plastik biodegradable dari tandan kosong kelapa sawit dengan penguat zink oksida dan gliserol. Penelitian ini bertujuan untuk mengetahui kekuatan tarik film plastik biodegradable yang dihasilkan dari tandan kosong kelapa sawit dengan variasi $\mathrm{ZnO}$ dan gliserol (a) $0 \% \mathrm{ZnO}$ dan 50\% gliserol; (b) $2 \% \mathrm{ZnO}$ dan 25\% gliserol; (c) 9\% ZnO dan 25\% gliserol; (d) 3\% ZnO dan $50 \%$ gliserol. Metode penelitian yang digunakan adalah analisis sifat mekanik dan uji kekuatan tarik film plastik menggunakan Universal Testing Machine (UTM). Hasil penelitian menunjukan bahwa kuat tarik pada film plastik biodegradable dipengaruhi oleh konsentrasi gliserol dan $\mathrm{ZnO}$. Kuat tarik maksimal yang didapat dari penelitian yaitu 12,642 MPa dengan komposisi gliserol 25\% dan $\mathrm{ZnO}$ 9\%. Hal ini menunjukkan bahwa semakin banyak penambahan komposisi gliserol dan $\mathrm{ZnO}$ maka kuat tarik plasik akan semakin baik.
\end{abstract}

Kata kunci : biodegradable film, kuat tarik, tandan kosong kelapa sawit

\section{PENDAHULUAN}

Dalam kehidupan manusia modern, penggunaan produk-produk kemasan plastik cenderung terus meningkat seiring dengan semakin tingginya konsumsi dan daya beli masyarakat. Berdasarkan data Dirjen Pengelolaan Sampah, Limbah, dan B3 KLKH (2016), pada tahun 2019 sampah plastik di Indonesia diperkirakan akan mencapai 9,52 juta ton atau $14 \%$ dari total sampah yang ada. Peningkatan tersebut banyak menimbulkan masalah antara lain yaitu masalah pencemaran lingkungan dan memicu terjadinya krisis minyak tanah (Berkesch, 2005).

Salah satu jenis dari plastik sintetis adalah polietilena berdensitas tinggi (High Density Polyethylene, HDPE). HDPE memiliki nilai kuat tarik sebesar 3100-5500 Psi dengan elongasi sebesar 100\%. HDPE memiliki sifat bahan yang lebih keras, kuat, buram, dan lebih tahan terhadap suhu yang tinggi. Meskipun memiliki kekuatan mekanik yang tinggi plastik ini tidak dapat didegradasi oleh lingkungan, untuk mengatasi masalah tersebut dilakukan pembuatan plastik biodegradable dengan 
mencampurkan plastik sintetis dengan polimer alam (Billmeyer, 1984).

Tandan kosong kelapa sawit merupakan limbah padat terbesar yang dihasilkan oleh perkebunan kelapa sawit yaitu sebanyak 22-23\% (Fuadi dan Pranoto, 2016). Menurut Darnoko (1992), komposisi kimiawi tandan kosong kelapa sawit antara lain Selulosa bobot kering 45,95 \%, Hemiselulosa bobot kering 22,84\%, lignin bobot kering 16,49\%, kadar abu bobot kering 1,23\% dan kadar air bobot kering 3,74\%.

Tandan kosong kelapa sawit dapat digunakan sebagai alternatif bahan dasar plastik biodegradable karena memiliki kandungan selulosa yang cukup tinggi. Plastik biodegradable dapat menggunakan beberapa polimer alami, seperti protein, pati, dan bakteri (Gonzales-Gutierrez dkk., 2010). Biodegradable film dapat terbuat dari polisakarida yang berasal dari tumbuhan seperti selulosa, pati dan agaragar (Wekridhany et al., 2012). Pati merupakan salah satu polimer alami dari ekstraksi tanaman yang dapat digunakan untuk memproduksi material biodegradable karena sifatnya yang ramah lingkungan, mudah terdegrasi, ketersediaan yang besar, dan terjangkau (Gonzalez-Gutierre dkk., 2010). Penggunaan serat sebagai plastik memiliki kelemahan yaitu kuatnya prilaku hidrofilik dan sifat mekanis yang lebih buruk jika dibandingkan dengan polimer sintetis (Wang, 2008).

Untuk meningkatkan kekuatan mekanis, sejumlah kecil pengisi (filler) berupa bahan inorganik biasanya ditambahkan ke dalam matriks polimer. Zink dioksida ( $\mathrm{ZnO})$ merupakan salah satu filler yang menarik digunakan karena $\mathrm{ZnO}$ adalah keramik piezoelektrik dan bersifat antimikroba (Wang, 2008).

Dalam pembuatan plastik biodegradable ini juga memerlukan gliserol sebagai material perekat antara polimer inti yang sering digunakan. Kegunaan material perekat atau plastisasi memacu proses pencentakan dan meningkatkan fleksibilitas produk (Zhong,
2008). Selain itu, Gliserol merupakan bahan yang murah, sumbernya mudah diperoleh dapat diperbaharui, dan juga akrab dengan lingkungan karena mudah didegradasi oleh alam (Zhong, 2008).

Kuat tarik merupakan salah satu sifat mekanik biodegradable film yang sangat penting, karena biodegradable film yang memiliki kekuatan tarik tinggi akan mampu melindungi produk yang dikemasnya dari gangguan mekanis (Wahyuni, 2001). Nilai standar kuat tarik biodegradable film untuk plastik jenis polyethylene (LDPE) yaitu 9,86 MPa dan polypropylene yaitu 33,80 Mpa (Boedeker plastic, 2013).

\section{METODE PENELITIAN}

Penelitian ini dilaksanakan di Laboratorium Kimia Universitas Negeri Medan dan Laboratorium Polimer Universitas Sumatera Utara, pada bulan April sampai Juni 2017.

Bahan utama yang digunakan untuk pembuatan biodegradable film dalam penelitian ini adalah tandan kosong kelapa sawit yang diperoleh dari PKS PTPN 2 Pagar Merbau, penguat (filler) sebagai pengisi plastik yaitu nano partikel seng oksida $(\mathrm{ZnO})$, dan gliserol sebagai pemlastis. Sedangkan bahan pendukung lain yang digunakan adalah aquades, $\mathrm{HNO}_{3} 3,5 \%, \mathrm{NaNO}_{2}, \mathrm{NaOH} 2 \%$, $\mathrm{Na}_{2} \mathrm{SO}_{3} 2 \%, \mathrm{NaOCl} 1,75 \%, \mathrm{NaOH} 17,5 \%, \mathrm{H}_{2} \mathrm{O}_{2}$ $10 \%$, etanol, CMC, dan larutan isopropanol. Peralatan yang digunakan dalam penelitian yaitu: neraca analitis; ultrasonikasi; hot plate; oven; termometer; cetakan flexiglass; spaltula; indikator universal; kertas saring; dan peralatan gelas laboratorium seperti beaker gelas, cawan petri, spatula kaca, gelas ukur, dan pipet volume.

\section{Pembuatan Plastik Biodegradable Isolasi Selulosa Dari Tandan Kosong Kelapa Sawit}

(1:1) yang berjumlah $750 \mathrm{ml}$ pada suhu $50^{\circ} \mathrm{C}$ selama dua jam.Kemudian campuran 
disaring dan dicuci hingga didapat ampas dengan filtrat netral. Tahap berikutnya proses pemutihan yang dilakukan dengan melarutkan ampas sampel ke dalam $250 \mathrm{ml} \mathrm{NaOCl} \mathrm{1,75 \%}$ pada temperatur mendidih selama 30 menit. Kemudian campuran disaring dan dicuci sampai 27 filtrat dari ampas sampel netral. Pemurnian $\alpha$-selulosa dilakukan dengan cara sampel dilarutkan ke dalam $500 \mathrm{ml} \mathrm{NaOH} \mathrm{17,5 \%} \mathrm{pada}$ suhu $80^{\circ} \mathrm{C}$ selama 30 menit. Selanjutnya campuran disaring dan dicuci sampai filtrat ampas netral. Tahap akhir, sampel dilarutkan ke dalam larutan $\mathrm{H}_{2} \mathrm{O}_{2}$ 10\% selama satu jam.Sampel yang didapatkan disaring dan dicuci sampai filtrat ampas netral. Kemudian ampas (pulp) yang didapat dioven pada suhu $60^{\circ} \mathrm{C}$ hingga diperoleh bobot konstan (Nurul, 2016).

\section{Pembuatan Carboxy Methyl Cellulose (CMC)}

Pada proses pembuatan CMC, sebanyak 10 gram alfa selulosa dimasukkan ke dalam campuran isopropanol-isobutanol sebanyak 80:20 $\mathrm{mL}$ dan diaduk selama 10 menit. Kemudian tahap alkalisasi dilakukan dengan menambahkan 30 ml larutan $\mathrm{NaOH} 10 \%$ ke dalam labu reaksi selama 1 jam, penambahan $\mathrm{NaOH}$ dilakukan dengan setetes demi setetes pengadukan pada suhu ruang. Setelah itu dilanjutkan dengan proses karboksimetilasi dengan menambahkan $\mathrm{ClCH}_{2} \mathrm{COONa}$ sebanyak 12 gram ke dalam labu reaksi pada suhu $55^{\circ} \mathrm{C}$ dengan sedikit demi sedikit dan diaduk selama 3,5 jam. Selama kedua proses ini berlangsung pengaduk tetap berputar Setelah proses karboksimetilasi selesai, Selanjutnya ditambah $\mathrm{CH}_{3} \mathrm{COOH}$ sampai $\mathrm{pH}$ netral dan didekantasi. Residu yang didapatkan ditambah dengan etanol 96\% diaduk kemudian disaring. Kemudian dibungkus dalam aluminium foil dikeringkan dalam oven selama 4 jam pada suhu $60^{\circ} \mathrm{C}$. CMC yang telah kering ini kemudian dihaluskan dan disimpan dalam tempat tertutup.

\section{Pembuatan Film Plastik Biodegradable}

Proses pembuatan plastik dapat dilakukan melalui langkah-langkah sebagai berikut: Mencampurkan 0,5 gram pati dan 0,5 gram
CMC ke dalam air. Diaduk hingga menjadi gel. Memasukkan Selulosa yang telah dipanaskan dengan air ke dalam larutan kemudian memasukkan komposisi Nano $\mathrm{ZnO}$ dan Gliserol dengan berbagai variasi Variasi penguat film plastik yang digunakan yaitu: (A) $0 \% \mathrm{ZnO}$ dan $50 \%$ gliserol; (B) $2 \% \mathrm{ZnO}$ dan $25 \%$ gliserol; (C) 9\% $\mathrm{ZnO}$ dan $25 \%$ gliserol; (D) $3 \% \mathrm{ZnO}$ dan 50 $\%$ gliserol

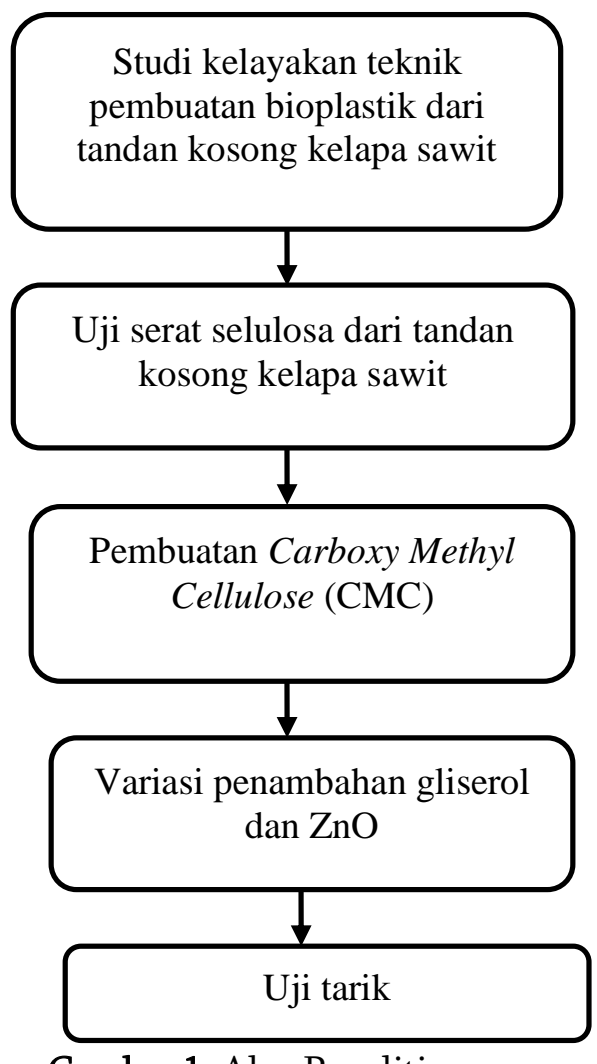

Gambar 1. Alur Penelitian

\section{Uji Kekuatan Tarik}

Uji kuat tarik diukur dengan alat Universal Testing Machine MPY (Type: Gotech AI-7000M, Ltd Tokyo, Japan). Sebelum dilakukan uji kekuatan tarik, disiapkan lembaran film plastik biodegradable dengan ukuran 6,4 x 0,6 cm dan dikondisikan di laboratorium dengan kelembaban ( $\mathrm{RH}$ ) $50 \%$ selama 48 jam. Instron diset pada initial grip separation $50 \mathrm{~mm}$, crosshead speed 50 $\mathrm{mm} /$ menit dan loadcell $50 \mathrm{~kg}$.

Film plastik dipotong sesuai dengan standar ASTM-D638 seperti ditunjukkan pada Gambar 1. 


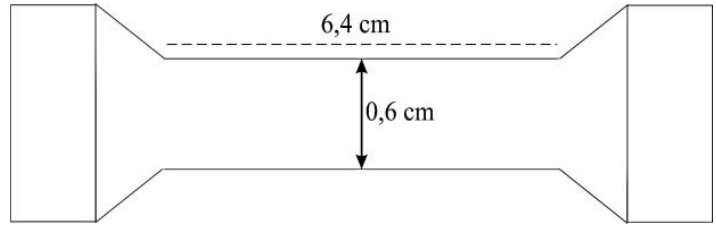

Gambar 2. Bentuk Spesimen Uji Kekuatan Tarik

Pengujian dilakukan dengan cara kedua ujung sampel dijepit mesin penguji tensile. Selanjutnya dicatat panjang awal dan ujung tinta pencatat diletakkan pada posisi 0 pada grafik. Dinyalakan knob start dan alat akan menarik sampel sampai putus dan dicatat gaya kuat tarik (F) dan panjang setelah putus. Pengukuran elongasi dan modulus Young dilakukan dengan cara yang sama dengan pengujian kuat tarik (Susilawati, 2011).

\section{HASIL DAN PEMBAHASAN}

Persiapan bahan baku utama, yaitu tandan kosong kelapa sawit. Tandan kosong diperoleh dari perkebunan kelapa sawit PKS PTPN 2 Pagar Merbau. TKS direndam selama 6-7 jam, kemudian dicacah dan dikeringkan (dijemur). Kemudian memperkecil ukuran tandan dari ukuran awal tandan mula-mula.

\section{Isolasi Selulosa Dari Tandan Kosong Kelapa} Sawit

Tahap isolasi selulosa dari tandan kosong kelapa sawit pada penelitian ini dilakukan berdasarkan metode isolasi selulosa oleh Ohwoavworhua dalam Fenny Aulia dkk (2013). Hasil penelitian ini, berupa pulp yang berwarna putih. Proses terakhir dilakukan pemutihan menggunakan hidrogen peroksida $10 \%$ dan di keringkan dalam oven pada suhu $60^{\circ} \mathrm{C}$. Untuk mengetahui kadar selulosa yang diperoleh, maka dilakukan penggabungan terhadap hasil isolasi selulosa yang telah dikeringkan. Dimana berat yang hilang dalam proses pengabuan ini dihitung sehingga didapat kadar selulosa yang diperoleh dari hasil isolasi tandan kosong kelapa sawit adalah 78,12\%.

\section{Pembuatan Filler ZnO dan Film Plastik Biodegradable}

Proses pembuatan filler $\mathrm{ZnO}$ dilakukan dengan metode sonikasi dengan mencampurkan logam $\mathrm{ZnO} 10$ gram kedalam isopropanol $200 \mathrm{~mL}$, kemudian dimasukkan ke dalam alat ultrasonik batch. Proses ini dilakukan di Laboratorium Kimia Analitik USU. Hasilnya adalah serbuk $\mathrm{ZnO}$ berwarna putih. Tahap terakhir yaitu pembuatan plastik biodegradable dengan mencampurkan $\mathrm{ZnO}$ dan gliserol ditambah dengan $100 \mathrm{~mL}$ aquades. Kemudian campuran dimasukkan ke dalam ultrasonik batch selama 1 jam. Hasilnya terbentuk larutan dua fasa. Campuran tersebut dipanaskan di atas hot plate selama $80-90^{\circ} \mathrm{C}$ ditambahkan dengan selulosa, kemudian campuran dimasukkan dalam flexi glass dan di oven selama 60 menit dengan suhu $100^{\circ} \mathrm{C}$. Setelah itu hasil yang diperoleh adalah lembaran putih seperti kertas bukan plastik. Sehingga penelitian ini masih dalam tahap pembuatan plastik biodegradable, penelitian akan terus dilakukan hingga menghasilkan plastik yang diinginkan.

\section{Uji Kekuatan Tarik}

Sifat mekanik plastik merupakan karakteristik utama dan memegang peranan penting. Sifat mekanik yang diuji dalam penelitian ini meliputi kuat tarik, elongasi, dan modulus Young. Kuat tarik merupakan indikasi kekuatan yang paling penting dari suatu bahan. Pengukuran kuat tarik biasanya diikuti dengan pengukuran perpanjangan putus. Perpanjangan putus menentukan keelastisan suatu plastik. Semakin tinggi nilai perpanjangan putus maka plastik tersebut semakin elastis sehingga bahan tersebut dapat ditarik lebih mulur. Plastik dengan perpanjangan putus yang rendah akan bersifat rapuh (Shah dkk. (2008) dalam Inggaweni dan Suyatno, 2015). Spesimen plastik dikarakterisasi dengan instrumen autograph dengan standar ASTM-D638. 
Tabel 1. Hasil Pengukuran Uji Kekuatan Tarik Film Plastik Biodegradable dari Tandan Kosong Kelapa Sawit dengan Penguat $\mathrm{ZnO}$ dan Gliserol

\begin{tabular}{|c|c|c|c|c|}
\hline \multicolumn{2}{|c|}{ Variasi Penguat Film Plastik } & \multirow{2}{*}{$\begin{array}{c}\text { Tensile Strenght } \\
(\mathrm{MPa})\end{array}$} & \multirow{2}{*}{$\begin{array}{c}\text { Persen Elongasi } \\
\text { (\%) }\end{array}$} & \multirow{2}{*}{$\begin{array}{l}\text { Modulus Young } \\
\text { (MPa) }\end{array}$} \\
\hline $\mathrm{ZnO}$ & Gliserol & & & \\
\hline $0 \%$ & $50 \%$ & 0,686 & 497,585 & 0,139 \\
\hline $2 \%$ & $25 \%$ & 0,392 & 77,177 & 0,508 \\
\hline $3 \%$ & $50 \%$ & 12,642 & 23,704 & 53,334 \\
\hline $9 \%$ & $25 \%$ & 8,526 & 19,308 & 44,159 \\
\hline
\end{tabular}

Pada penelitian ini, nilai kuat tarik biodegradable film yang diperoleh yaitu berkisar antara 0686-12,642 Mpa dengan nilai tertinggi sebesar 12,642 MPa dengan variasi 9\% ZnO dan $25 \%$ gliserol. Nilai kuat tarik biodegradable film pada penelitian ini sudah sesuai dengan standar untuk plastik jenis polyethylene (LDPE) yaitu 9,86 MPa dan polypropylene yaitu 33,80 Mpa (Boedeker plastic, 2013) sehingga dapat dikatakan film plastik dapat digunakan untuk mengemas produk sesuai standar plastik konvensional.

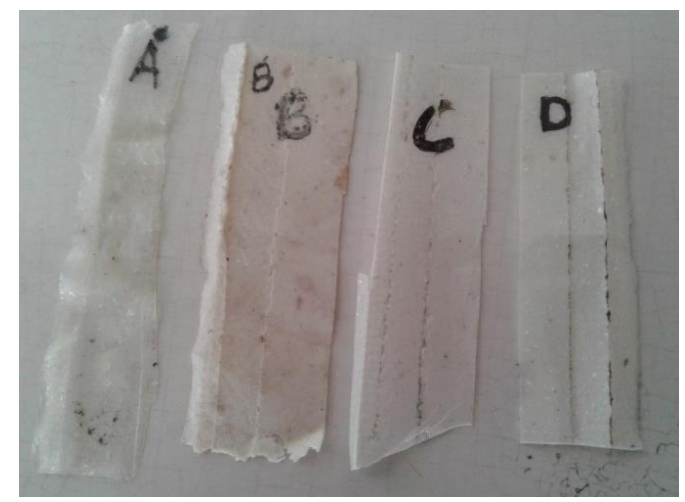

Gambar 3. Film Plastik Biodegradable dari Tandan Kosong Kelapa Sawit dengan Penguat $\mathrm{ZnO}$ dan Gliserol

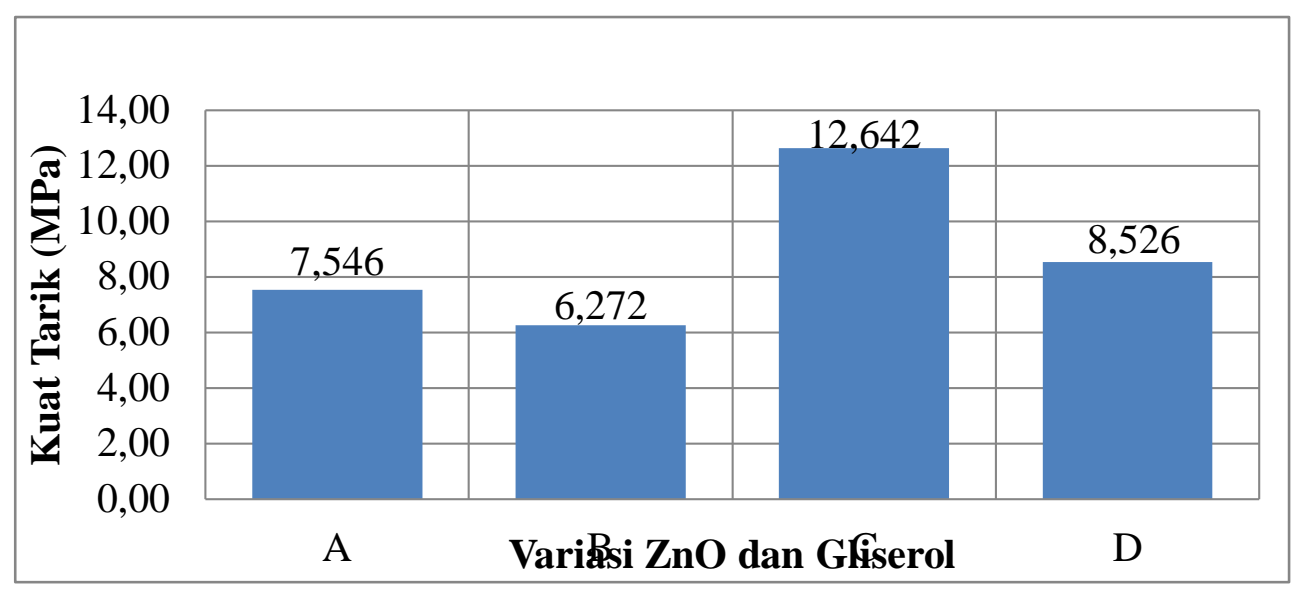

Gambar 4. Hasil Pengukuran Uji Kekuatan Tarik (Tensile Strenght) Film Plastik Biodegradable

Berdasarkan hasil analisis ragam banyak gliserol yang digunakan maka kuat menunjukkan bahwa konsentrasi gliserol dan tariknya semakin bagus. Variasi penguat plastik berat $\mathrm{ZnO}$ berpengaruh pada kuat tarik yang digunakan yaitu dengan 9\% $\mathrm{ZnO}$ dan $25 \%$ biodegradable film yang dihasilkan. Semakin gliserol, merupakan variasi optimum yang dapat 
Agustina Mandasari, Mutya Fika Safitri, Essy Risa Perangin-angin, Dian Sunarwati, Wulan Dwi Safitri dan Hafni Indriati Nasution, Karakterisasi Uji Kekuatan Tarik (Tensile Strenght) Film Plastik Biodegradable Dari Tandan Kosong Kelapa Sawit Dengan Penguat Zink Oksida Dan Gliserol

menghasilkan film plastik dengan kualitas uji tarik yang terbaik.

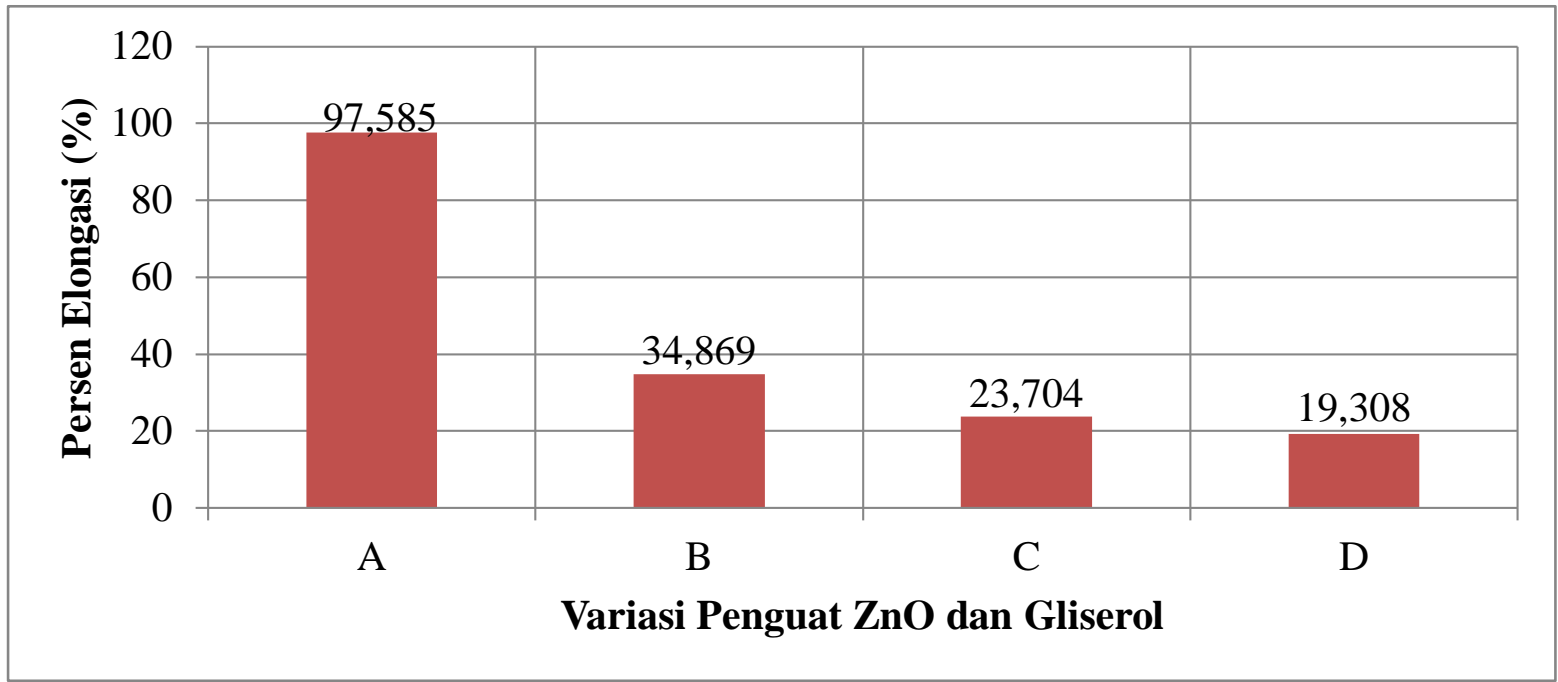

Gambar 4. Hasil Pengukuran Person Elongasi Film Plastik Biodegradable

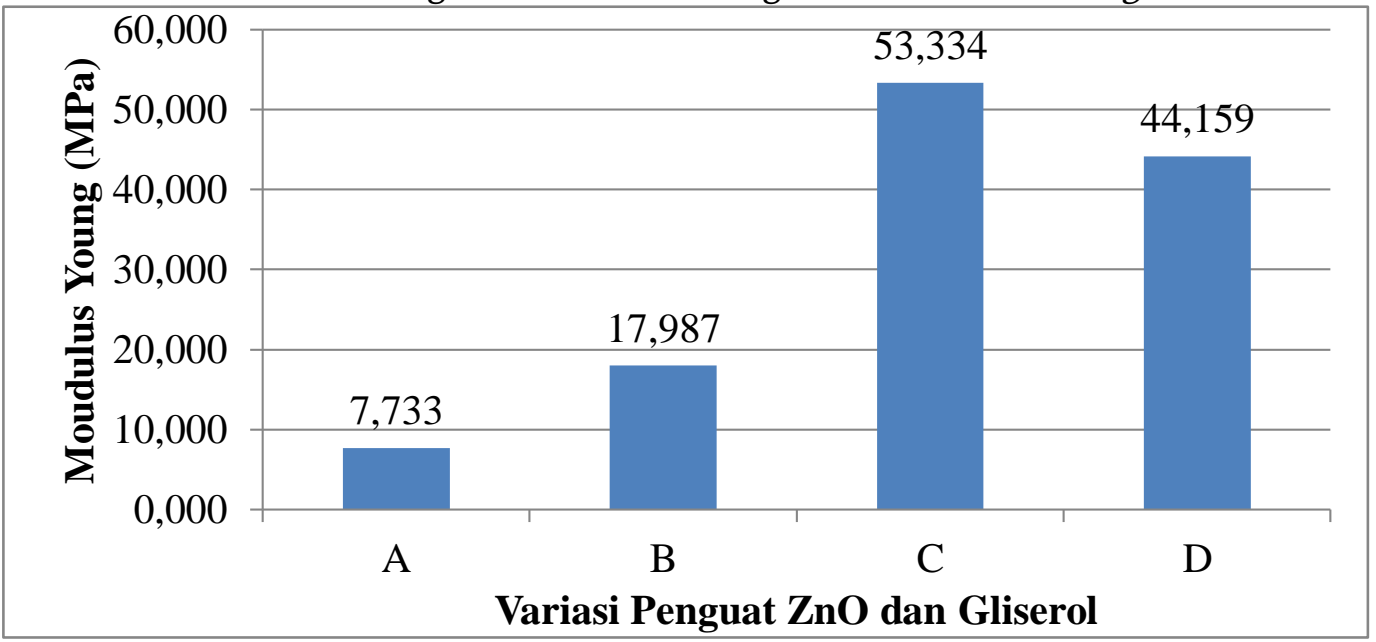

Gambar 5. Hasil Pengukuran Modulus Young Film Plastik Biodegradable

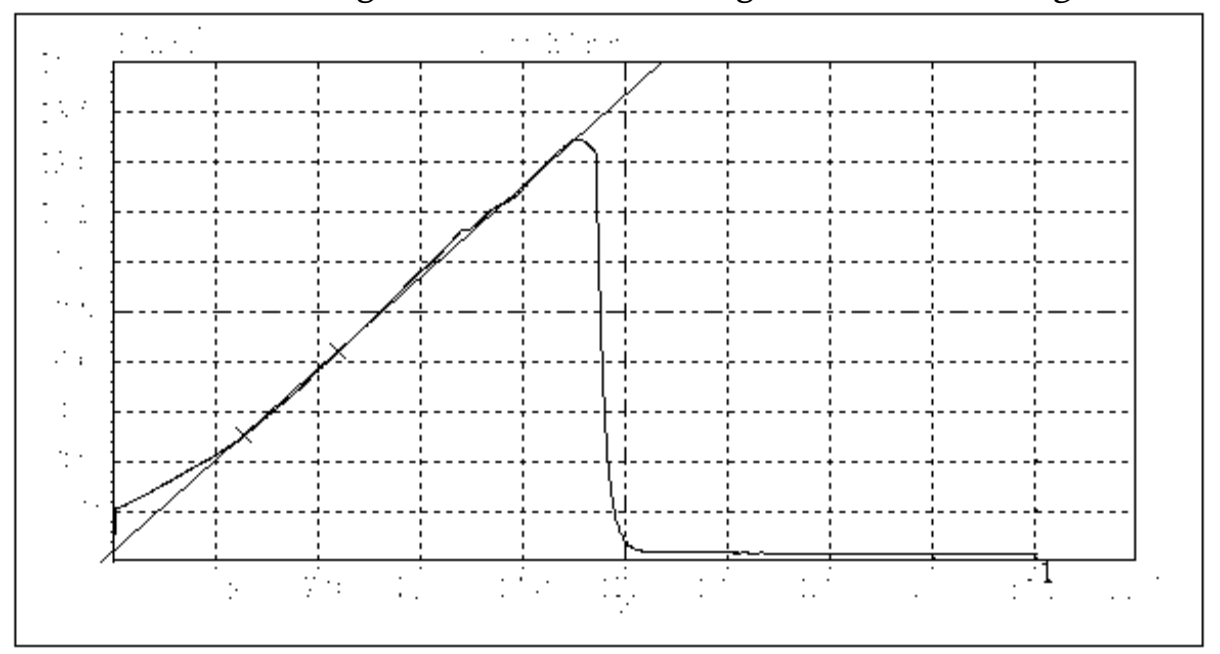

Gambar 6. Grafik Uji Kekuatan Tarik (Tensile Strenght) Film Plastik Biodegradable dengan Variasi 9\% $\mathrm{ZnO}$ dan $25 \%$ Gliserol 


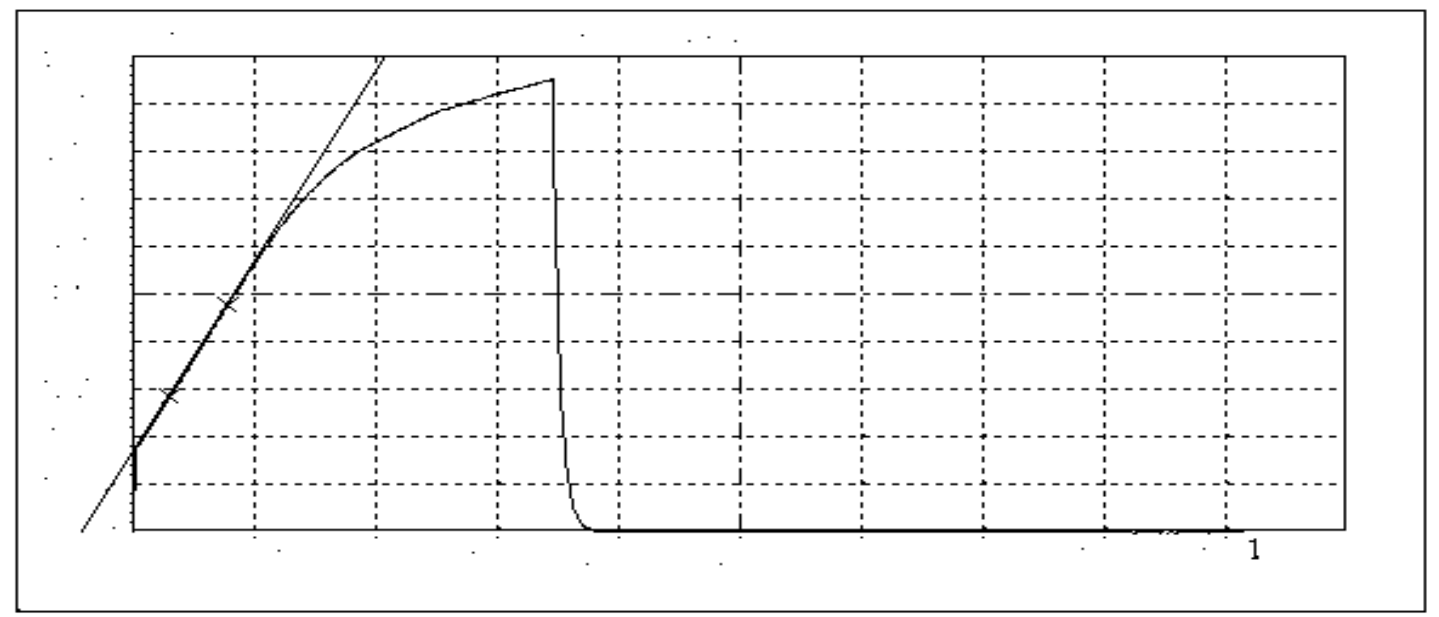

Gambar 7. Grafik Uji Kekuatan Tarik (Tensile Strenght) Film Plastik Biodegradable dengan Variasi 3\% $\mathrm{ZnO}$ dan 50\% Gliserol

\section{KESIMPULAN}

Hasil penelitian menunjukan bahwa kuat tarik pada film plastik biodegradable dipengaruhi oleh konsentrasi gliserol dan $\mathrm{ZnO}$. Variasi penguat film plastik yang digunakan yaitu 9\% $\mathrm{ZnO}$ dan 25\% gliserol merupakan

\section{DAFTAR PUSTAKA}

Anita, Z., Akbar, F., Harahap, H. 2013. Pengaruh Penambahan Gliserol Terhadap Sifat Mekanik Film Plastik Biodegradasi Dari Pati Kulit Singkong. Jurnal Teknik Kimia USU, 2(2): 38.

Aulia, F., Marpongahtun., Gea, S. 2013. Studi Penyediaan Nanokristal Selulosa Dari Tandan Kosong Sawit (Tks). Jurnal Saintia Kimia,1(2).

Averous, L. 2012. Bioodegradable Polymers. Environmental Silicate NanoBiocomposites Journal, ISBN: 978-1-44714101-3.

Badan Pusat Statistik (BPS). 2015. Luas Tanaman Perkebunan Berdasarkan Provinsi dan Jenis Tanaman.

Berkesch, Shellie. 2005. Biodegradable Polymers. USA: Michigan State University.

Billmeyer, F. W. Jr. 1984. Text Book of Polimer Science. New York: John Willey dan Sons Inc. variasi optimum yang memiliki kualitas kekuatan tarik maksimal, yaitu sebesar 12,642 MPa. Hal ini menunjukkan bahwa semakin banyak penambahan komposisi gliserol dan $\mathrm{ZnO}$ maka kuat tarik plasik akan semakin baik.

Boedeker plastic. 2013. Polyethylene Specification.

http://www.boedeker.com/polye_p.htm. Diakses pada tanggal 2 Juni 2017.

Coniwati, P., Laila, L \& Alfira, M. R. 2014. Pembuatan Film Plastik Biodegredable Dengan Penambahan Kitosan Dan Pemplastis Gliserol. Jurnal Teknik Kimia, 4(20): 23.

Darnoko. 1992. Potensi Pemanfaatan Limbah Lignoselulosa. Kelapa Sawit. Melalui Biokonversi, berita Pen. Perkeb.2. Hal 8597

Dirjen Pengelolaan Sampah, Limbah, dan B3 KLKH. 2016. Statistik Kementrian Lingkungan Hidup dan Kehutanan.

Fuadi, A. M., dan Pranoto, H. 2016. Pemanfaatan Limbah Tandan Kosong Kelapa Sawit Sebagai Bahan Baku Pembuatan Glukosa. Chemica, 3(1): 1-5.

Gonzalez-Gutierrez, J., P.Partal., M. GarciaMorales., dan Gallegos, C. 2010. Development of highly-transparent 
protein/starch-based

bioplastics.

Bioresource Tecnology, 101-109.

Liantika. 2011. Pembuatan Film Plastik Dari

Limbah Ubi Kayu Dengan Pemplastis

Gliserol. Palembang: Universitas

Sriwijaya.

Satriyo. 2012. Kajian Penambahan Chitosan,

Gliserol, dan Cmc Terhadap Karakteristik

Biodegradable Film Dari Bahan Komposit

Nanas. Lampung: Skripsi Jurusan

Teknologi Hasil Pertanian Fakultas

Pertanian Universitas Lampung.

Susilawati, Mustafa, I., dan Maulina, Desi. 2011. Biodegradable Plastic From A Mixture Of Low Density Polyethylene (LLDPE) And Cassava Starch with The Addition Of Acrylic Acid. Jurnal Natural. 11(2): 69-73.

Wahyuni, S. 2001. Mempelajari karakteristik fisik dan kimia edible film dari gelatin tulang domba dengan plasticizer gliserol. (Skripsi). Bogor: Jurusan Ilmu Produksi Ternak, Fakultas Peternakan, IPB.

Wang, Ning. 2009. Effect of citric acid and processing on the performance of thermoplastic starch/ montmorillonite nanocomposite. Carbohydrate Polimer 76: 68-73

Wekridhany, A., Y. Darni dan D. Agustina. 2012. Pengaruh rasio selulosa/NaOH pada tahap alkalinisasi terhadap peningkatan produksi natrium karboksimetilselulosa (Na-CMC) dari residu rumput laut eucheuma spinossum. Jurnal Penelitian. Jurusan Teknik Kimia, Fakultas Teknik. Universitas Lampung: 8.

Winarno, F. G. 1997. Kimia Pangan dan Gizi. Jakarta: Gramedia. 